ORIGINAL RESEARCH

\author{
S. Albayram \\ S. Saip \\ Z.I. Hasiloglu \\ M. Teke \\ E. Ceyhan \\ M. Tutuncu \\ H. Selcuk \\ A. Kina \\ A. Siva
}

\section{Evaluation of Parenchymal Neuro-Behçet Disease by Using Susceptibility-Weighted Imaging}

BACKGROUND AND PURPOSE: Neurologic involvement in Behçet disease, also known as NBD, is one of the most devastating manifestations of the disease. The precise pathologic mechanism of parenchymal NBD lesions has not been established. We evaluated lesion characteristics and probable venous hemorrhage in parenchymal NBD by using SWI, and we compared the imaging results with conventional MR imaging sequences.

MATERIALS AND METHODS: We performed cranial MR imaging by using a $1.5 \mathrm{~T}$ scanner in 23 patients with a definitive diagnosis of parenchymal NBD. We compared the proportion of lesion detection and the performance of hemorrhagic detection with the T2 FSE, T2* GE, and SWI magnitude, and SWI mIP by using the $\chi^{2}$ test.

RESULTS: The proportion of lesion detection with both SWI magnitude and SWI MinMIP was significantly larger than that with $\mathrm{T} 2{ }^{*} \mathrm{GE}$. The proportions of lesion detection among all other pairs of methods were not significantly different according to the corresponding $P$ value $\left(\chi^{2}=17.4929, d f=\right.$ $3, P=.0006)$. Proportions of hypointense hemorrhagic lesions with T2 FSE and T2* GE were not significantly different, and likewise for the proportions of hypointense hemorrhagic lesions with SWI magnitude and SWI mIP. In contrast, the proportions of hypointense hemorrhagic lesions with SWI magnitude and SWI mIP were significantly larger than that with T2 FSE and T2* GE $\left(\chi^{2}=108.5396\right.$, $d f=3, P<.0001)$.

ConcLusions: Most of the lesions in parenchymal NBD were found to be hemorrhagic with SWI, supporting the proposed venous theory in pathology. In addition, compared with T2 FSE and T2*GE sequences, SWI was more successful in the determination of widespread involvement of the disease, particularly in nonchronic cases.

ABBREVIATIONS: $\mathrm{BD}=$ Behçet disease; $\mathrm{BSA}=$ brain stem atrophy; $\mathrm{CC}=$ corpus callosum; $\mathrm{CV}=$ collateral vein; $\mathrm{mIP}=$ minimum intensity projection; $\mathrm{NBD}=$ neuro-Behçet disease; PVS = prominent venous structure; SWI = susceptibility-weighted imaging; T2 FSE = T2-weighted fast spin-echo; $\mathrm{T} 2{ }^{*} \mathrm{GE}=\mathrm{T} 2{ }^{*}$-weighted gradient-echo; TSV $=$ thalamostriate vein
$\mathbf{B}^{\mathrm{D}}$ was first reported by the Turkish dermatologist Hulusi Behçet who described 3 cases of recurrent oral and genital ulceration with uveitis. ${ }^{1}$ Although this classic triad remains diagnostically important, $\mathrm{BD}$ has emerged as a multisystem disorder. ${ }^{2-4}$ Neurologic involvement in BD (also known as NBD) is one of the most devastating manifestations of the disease and usually occurs 1-10 years after the first symptom of $\mathrm{BD}$ has appeared. Other symptoms of $\mathrm{BD}$ usually precede its neurologic complications. However, when the first symptom of $\mathrm{BD}$ is neurologic, as in $3 \%$ of cases, diagnosis of the disease becomes challenging. NBD is subclassified into 2 major forms: parenchymal and nonparenchymal. The 2 types rarely occur in the same individual, and their pathogeneses are probably

Received October 13, 2010; accepted after revision November 6

From the Department of Radiology (S.A., Z.I.H.), Division of Neuroradiology, Department of Neurology (S.S., M. Tutuncu, A.S.), Cerrahpasa Medical Faculty, Istanbul University, Kocamustafapasa, Istanbul, Turkey; Department of Radiology (M. Teke, A.K.), Taksim Ilk Yardım Research and Education Hospital, Istanbul, Turkey; Department of Mathematics (E.C.), Koc University, Istanbul, Turkey; and Department of Radiology (H.S.), Division of Neuroradiology, Bakirkoy Dr. Sadi Konuk Research and Education Hospital, Bakirkoy, Istanbul, Turkey.

Disclosures: S.A., research support (including provision of equipment or materials): yes. Details: international drug company trials (investigator fee) especially multiple sclerosis and headache.

Please address correspondence to Sait Albayram, Department of Radiology, Division of Neuroradiology, Cerrahpasa Medical Faculty, Istanbul University, 34300 Kocamustafapasa, Istanbul, Turkey; e-mail: salbayram@hotmail.com

DOI 10.3174/ajnr.A2477 different. ${ }^{5,6}$ The precise pathologic mechanism of parenchymal NBD lesions has not been established. Parenchymal NBD lesions have been hypothesized to be venous infarcts ${ }^{7}$; however, this hypothesis needs more pathologic support because vasculitis cannot usually be demonstrated within parenchymal NBD lesions. ${ }^{8-12}$

SWI is a new neuroimaging technique that uses tissue magnetic susceptibility differences to generate a unique contrast and is different from spin attenuation, T1, T2, and T2*. SWI consists of using both magnitude and phase images and is very sensitive for the detection of venous deoxygenated blood products inside as well as outside of the blood vessels. ${ }^{13}$ The purpose of this study was to evaluate lesion characteristics in parenchymal NBD with SWI and to compare the results with conventional $\mathrm{MR}$ imaging sequences.

\section{Materials and Methods}

\section{Patients}

The study protocols were approved by our institutional review board, and informed consent was obtained from each patient. We evaluated 12 female and 11 male patients, ranging in age from 20 to 52 years (mean age, 37.95 years). In this study, the subjects were composed of follow-up patients with definitive diagnosis of $\mathrm{BD}$. All patients were referred from the Behçet Disease Research Center of our university hospital. Criteria established by the International Study Group for BD were used for diagnosis. ${ }^{14}$ We selected BD patients who had neuro- 
logic manifestations such as headache or neurologic deficit. Neurologic involvement was evaluated and defined by neurology consultants at the Research Center from the Department of Neurology, which referred the patients for MR examination. Patients with neurologic or other diseases involving the central nervous system, traumatic brain injury, and hypertension were excluded from this study. All patients were normotensive. The study period ranged from March 2009 to March 2010.

\section{Data Acquisition}

MR images were acquired by using a 1.5-T unit (Magnetom Avanto; Siemens, Erlangen, Germany) with a 12-channel head coil. The MR imaging protocols included transverse T2 FSE imaging (TR/TE, 4880/ $116 \mathrm{~ms}$; section thickness, $3 \mathrm{~mm}$; flip angle, $30^{\circ}$; echo-train length, 11 ; acquisition matrix, $512 \times 256 \mathrm{~ms}$; and FOV, $230 \mathrm{~mm}$ ), transverse T1-weighted spin-echo imaging (TR/TE, 375/11 ms; section thickness, $3 \mathrm{~mm}$; flip angle, $90^{\circ}$; acquisition matrix, $512 \times 256 \mathrm{~ms}$; and FOV, $230 \mathrm{~mm}$ ), and $\mathrm{T} 2{ }^{\star} \mathrm{GE}$ imaging (TR/TE, 829/26 ms; section thickness, $3 \mathrm{~mm}$; flip angle, $20^{\circ}$; acquisition matrix, $512 \times 256 \mathrm{~ms}$; and FOV , $230 \mathrm{~mm}$ ). The SWI was acquired with the following parameters: TR/TE, $57 / 40 \mathrm{~ms}$; section thickness, $2 \mathrm{~mm}$; flip angle, $20^{\circ}$; bandwidth, $80 \mathrm{~Hz} /$ pixel; acquisition matrix, $512 \times 256 \mathrm{~ms}$; FOV, $230 \mathrm{~mm}$; and acquisition time, 5 minutes). All images were acquired in the same axial plane. Subsequently, SWI sequences were reconstructed by using a mIP technique to obtain images with section number, thickness, and position similar to those of T2 FSE and T2* GE sequences. MR imaging data were anonymized before evaluation. All the imaging sequences, including SWI, were explained to the patients, and written informed consent was obtained.

\section{Imaging Analysis}

Two neuroradiologists (10 years of experience) reviewed the MR images independently by using a PACS (Carestream Health, Rochester, New York). Equivalent sections of T2 FSE, T2 ${ }^{\star} \mathrm{GE}$, SWI magnitude, and SWI mIP were compared simultaneously by using 2 linked 19inch monitors divided into 4 windows. T2 FSE, T2 ${ }^{\star} \mathrm{GE}$, SWI magnitude, and SWI mIP sequences were each evaluated for lesion existence, number, and localization. Lesion signals were classified as hyperintense and hypointense according to the neural parenchyma. Hemorrhagic foci were defined as hypointense signals on T2 FSE, T2 ${ }^{\star} \mathrm{GE}$, SWI magnitude, and SWI mIP, without continuity with surrounding vascular structures. Images were reviewed additionally for asymmetric prominent venous structures with irregular contours, defined as dilated and tortuous veins with ill-defined borders compared with the venous structures in the contralateral healthy parenchyma. Only deep venous occlusions were evaluated, and they were defined as abrupt discontinuity of the vein. Collateral venous structures were defined as venous structures adjacent to the lesion with an atypical pathway in the brain parenchyma. Brain stem atrophy was evaluated.

\section{Statistical Analyses}

We compared the performance of lesion detection with T2 FSE, $\mathrm{T} 2{ }^{*} \mathrm{GE}$, SWI magnitude, and SWI mIP by using the $\chi^{2}$ test. We first evaluated the equality of the proportion of lesion detection by using the $4 \mathrm{MR}$ imaging methods. If significant differences were found between them, we performed a pair-wise comparison to detect which methods significantly differed in lesion detection. The statistical tool used was the test of proportions for 2 or more groups. We tested the equality of the proportion of detected lesions by using the 4-sample test for equality of proportions without Yates' continuity correction (ie, at least 2 proportions are significantly different). Next, we performed the 2-sample test for equality of proportions with Yates' continuity correction to determine which pairs of proportions were significantly different and in which direction. Both $P$ values were adjusted for the 6 multiple pair-wise tests by using the Holm correction method.

We also compared the performance of the detection of hemorrhagic signal intensity with $\mathrm{T} 2 \mathrm{FSE}, \mathrm{T} 2{ }^{\star} \mathrm{GE}$, and SWI magnitude, and SWI mIP by using the $\chi^{2}$ test. We first tested the equality of the proportion of hypointense hemorrhagic lesion detection for the $4 \mathrm{MR}$ imaging methods. If significant differences were found between them, we performed a pair-wise comparison to detect which methods significantly differed in hypointense hemorrhagic lesion detection. The statistical tool used was the test of proportions for 2 or more groups. We tested the equality of the proportion of detected lesions by using the 4-sample test for equality of proportions without Yates' continuity correction. Next, we performed the 2-sample test for equality of proportions with Yates' continuity correction to determine which pairs of proportions were significantly different and in which direction. Both $P$ values were adjusted for the 6 multiple pair-wise tests by using the Holm correction method.

\section{Results}

Lesions were established in 21 of 23 patients. In one patient, we detected one lesion compatible with arterial ischemia in the corticosubcortical area of the left temporal lobe; however, this lesion was not included in the statistical analysis for comparison among sequences. In 2 of the remaining 22 patients, we did not establish any lesions because they had advanced brain stem atrophy, indicating that they were in the chronic stage of NBD. Thus, statistical analysis was performed in 20 patients. In total, 52 lesions were found in these patients. The number of the lesions ranged from 1 to 5 (mean \pm SD number of lesions, $2.52 \pm 1.36$ ). In SWI, the hemorrhagic lesions were apparent in our cases; therefore, we did not observe disagreement between 2 readers. Thus, a consensus conference was not deemed necessary. Localizations of lesions were as follows: 20 in the pons, 7 in the medulla oblongata, 6 in the putamen, 7 in the thalamus, 5 in the mesencephalon, 2 in the corona radiata, 3 in the caudate nucleus, 1 in the capsula interna, and 1 in the splenium of corpus callosum. A very high frequency of lesions occurred in the pons compared with other locations.

In total, 50 lesions were detected with SWI magnitude and SWI mIP, 43 lesions were detected with T2 FSE, and 38 lesions were detected with $\mathrm{T} 2{ }^{*} \mathrm{GE}$. The proportion of lesion detection with both SWI magnitude and MIP was significantly larger than that with $2^{\star} \mathrm{GE}(P=.0084$ and $P=.0084$, respectively $)$. The proportions of lesion detection between all others pairs of methods were not significantly different from the corresponding $P$ value $\left(\chi^{2}=17.4929, d f=3, P=.0006\right)$. For example, the proportions of lesion detection with SWI magnitude and T2 FSE were not significantly different $(P=.2230)$.

Hypointense hemorrhagic signals were detected with SWI magnitude and SWI mIP in 42 of 50 lesions, with T2 ${ }^{\star} \mathrm{GE}$ in 3 of 38 lesions, and with T2 FSE in 2 of 43 lesions. The proportions of hypointense hemorrhagic lesions with T2 FSE and $\mathrm{T} 2{ }^{\star} \mathrm{GE}$ were not significantly different $(P=1.0000)$ and likewise for the proportions of hypointense hemorrhagic lesions with SWI magnitude and SWI mIP. Conversely, the proportion of hypointense hemorrhagic lesions with SWI magnitude 

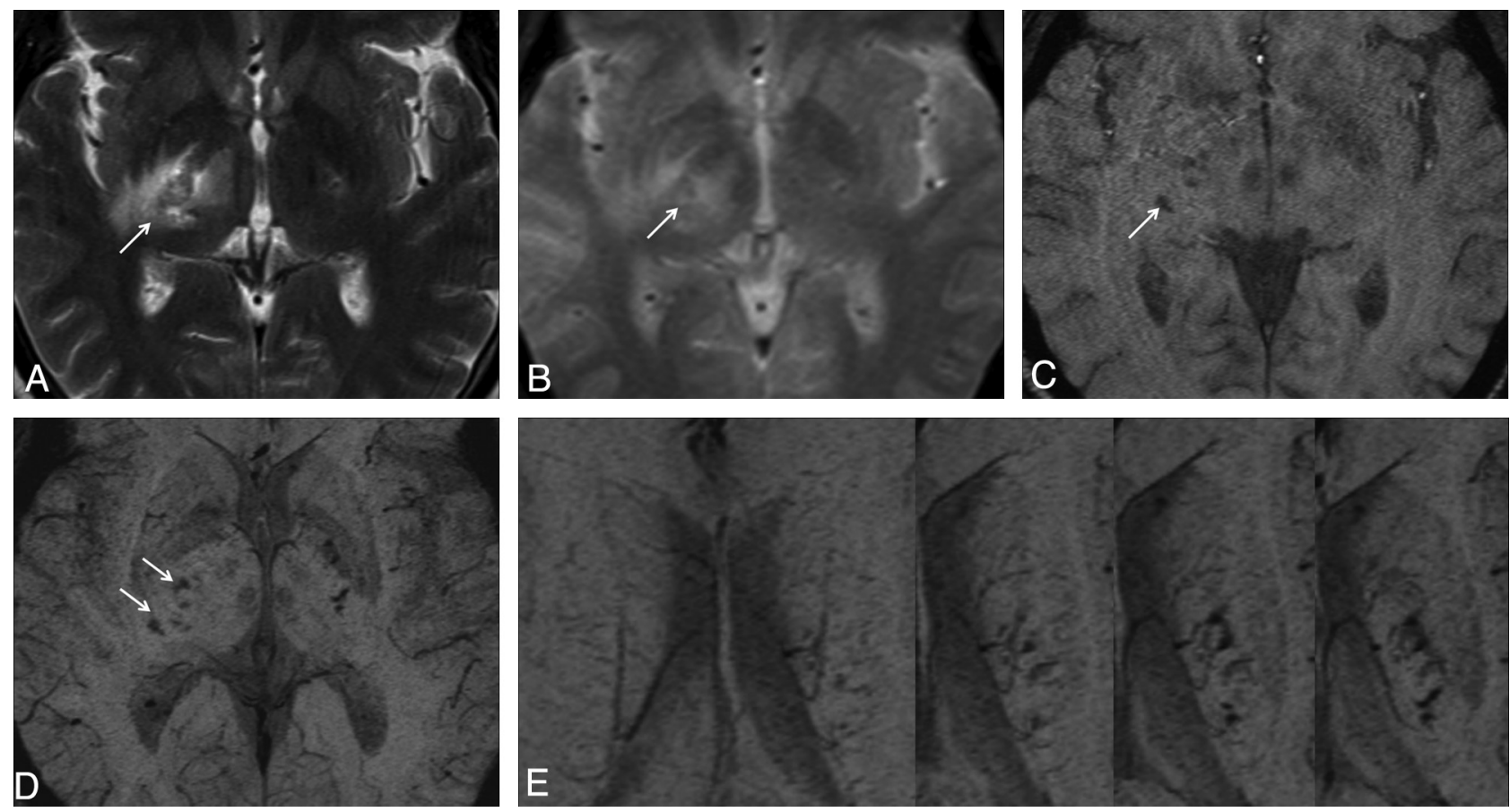

Fig 1. Case 16. Lesion in the right capsula interna is observed as hyperintense on T2 FSE $(A)$ and T2* $G E(B)$ images. In this localization, multiple hemorrhagic foci are observed as hypointense on SWI magnitude $(C)$ and SWI mIP $(D)$ images. In addition, prominent venous structures adjacent to the left corona radiata lesion are observed with continuity in consecutive sections on the SWI mIP $(E)$ image.

and SWI mIP were significantly larger than that with T2 FSE $(P<.0001)$ and $2^{*} \mathrm{GE}\left(P<.0001 ; \chi^{2}=108.5396, d f=3\right.$, $P<.0001)$.

Eight lesions that were detected with SWI could not be detected with $\mathrm{T} 2{ }^{\star} \mathrm{GE}$ or T2 FSE. Nine lesions that were detected with SWI could not be detected with T2 FSE. Fourteen lesions that were detected with SWI could not be detected with $\mathrm{T} 2{ }^{\star} \mathrm{GE}$. Two lesions that were determined to be hyperintense with T2 FSE and $\mathrm{T}^{\star} \mathrm{GE}$ could not be detected with SWI. Also, 6 patients had advanced brain stem atrophy. Around 6 lesions, prominent venous structures (Fig 1) were detected, whereas in 2 lesions, occlusion of the thalamostriate veins was detected. In one of the 2 lesions with occluded thalamostriate veins, a marked collateral venous structure was observed near the occluded vein (Fig 2). The established lesion characteristics in the present study are summarized in the Table.

\section{Discussion}

In the initial studies regarding parenchymal NBD, swelling of the brain stem, multiple foci of cell infiltration, and perivascular inflammatory cell cuffs were pathologically demonstrated. ${ }^{15,16}$ Rubinstein and Urich ${ }^{17}$ supported these neuropathologic findings and reported that lesions became increasingly chronic with extensive gliosis; atrophy; thickening and fibrosis of the meninges in some cases; and chronic relapse of inflammatory cellular infiltration around venules, capillaries, and occasionally arteries. In other studies, perivascular lymphocytic infiltration without fibrinoid necrosis, thrombosis, or endothelial degeneration were reported. ${ }^{18-21}$ In 1996, Hadfield et $\mathrm{al}^{22}$ reported the neuropathologic findings of an NBD patient in whom the frontal lobe, capsula interna, basal ganglia, cerebellum, and brain stem had acute, multifocal encephalitis, indicating numerous foci. In the con- clusion of their report, it was noted that vasculitis and consequent superimposed thrombosis for necrotizing lesions in NBD were seen in the absence of vessel wall inflammation. However, necrotizing lesions may be present because of primary acute neutrophilic inflammation. In 2004, Mirsattari et $\mathrm{al}^{11}$ hypothesized that an NBD patient with prompt atrophy of the brain and of generally all parts of the central nervous system (particularly the brain stem) involved chronic meningoencephalomyelitis. T-lymphocytes were exclusively present and showed perivascular cuffing. In 2008, Hirohata ${ }^{23}$ evaluated biopsied or autopsied brain tissues from acute NBD, chronic progressive NBD, and NBD in long-term remission. In acute NBD, infiltration of mononuclear cells around small vessels was revealed, as was apoptosis of most neurons. Infiltration of mononuclear cells also was observed around small vessels in the pons, cerebellum, medulla, capsula interna, and midbrain in the acute attack phase of chronic progressive NBD. In the biopsy of the inactive NBD patient, the most prominent features were atrophy of the brain stem and gliosis. Foci of mild infiltrations of mononuclear cells were still detected around small vessels. Hirohata ${ }^{23}$ suggested that soluble factors, including proinflammatory cytokines, were produced in neuronal apoptosis. Despite these findings, Scardamaglia et $\mathrm{al}^{24}$ reported a case with NBD where prominent fibrinoid necrosis was observed in small postcapillary venules, and there was surrounding acute and chronic inflammation, consistent with vasculitis, in a brain biopsy. Thus, the pathogenesis of NBD remains unclear, and the most accepted findings are perivascular lymphocytic infiltration without objective vasculitic infiltration.

SWI is a $3 \mathrm{D}$, long echo time, $\mathrm{T} 2{ }^{\star} \mathrm{GE}$ sequence technique that allows enhancement of local contrast by using a high-pass filtered phase mask, exploiting the magnetic properties of tis- 

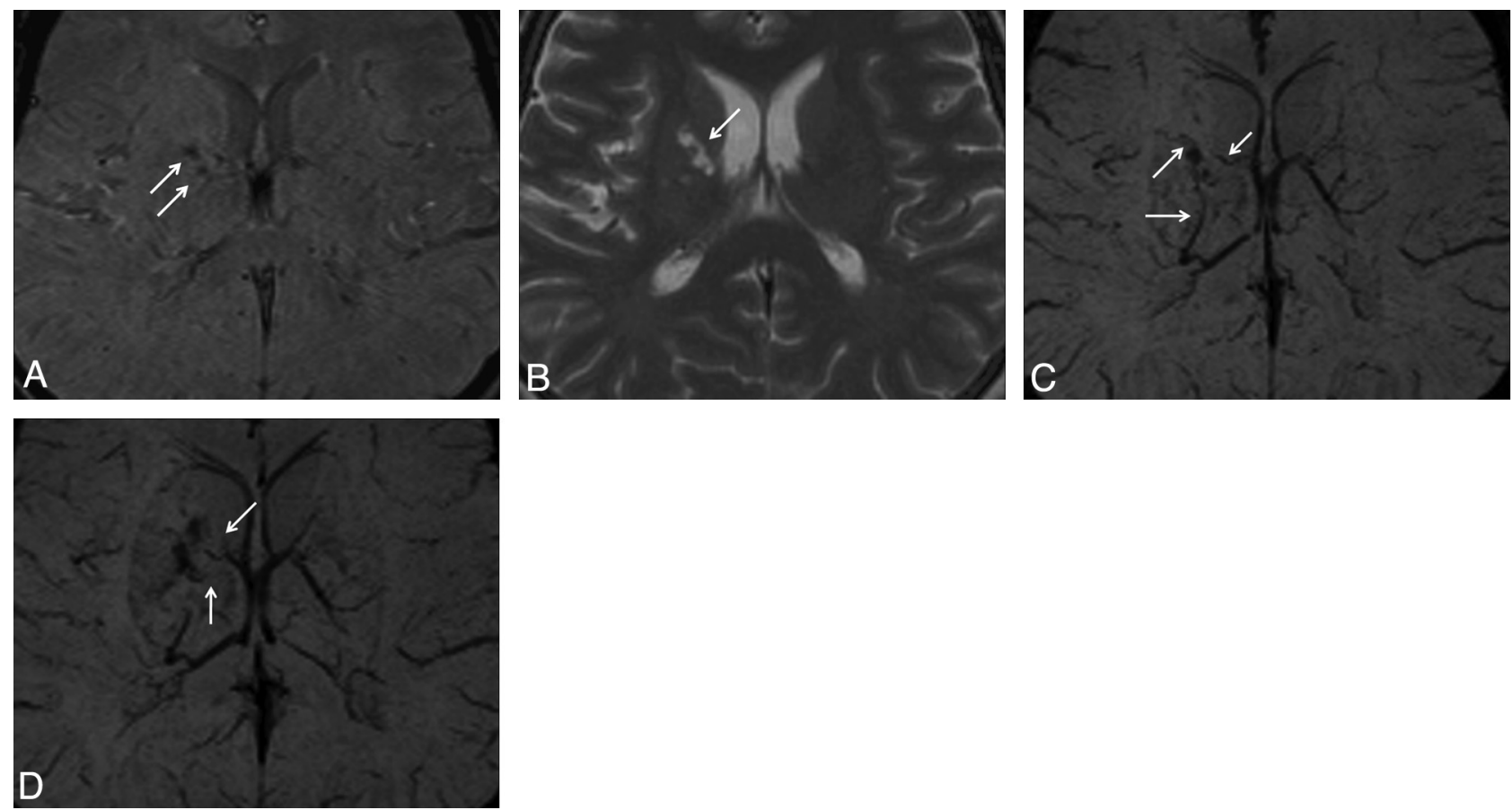

Fig 2. Case 20. Hemorrhagic lesion in the right putamen is observed as hypointense on the SWI magnitude (A) image. This lesion is observed as hyperintense on the T2 FSE (B) image. In the lesion vicinity, occlusion of thalamostriate veins $(C)$ and marked collateral venous structure $(D)$ are observed on the SWI mIP images.

sues, such as blood or iron-containing cells, that affect magnetic field inhomogeneity. ${ }^{25-27}$ SWI exploits the magnetic susceptibility differences between tissues, resulting in phase differences between regions containing paramagnetic deoxygenated blood products (deoxyhemoglobin, intracellular methemoglobin, or hemosiderin) and surrounding tissue. ${ }^{28}$ This method allows visualization of veins with diameters in the submillimeter range even with conventional $1.5 \mathrm{~T}$ whole body MR imaging systems. ${ }^{25}$ To detect venous vessels, the deoxygenation state of hemoglobin is used as an intrinsic contrast mechanism. ${ }^{29}$ SWI has been applied to various pathologies of the brain that affect magnetic inhomogeneity, such as stroke, ${ }^{30}$ trauma, ${ }^{31}$ cerebral cavernous malformation, ${ }^{32}$ arteriovenous malformation, ${ }^{33}$ pathophysiology affecting iron-storage conditions, ${ }^{34}$ intratumoral hemorrhages, ${ }^{35}$ and cerebral amyloid angiopathy. ${ }^{36} \mathrm{SWI}$ is particularly helpful for the evaluation of diffuse axonal injury that is often associated with punctate hemorrhages in the deep subcortical white matter, which are not routinely visible on CT or conventional MR imaging sequences. ${ }^{28}$ Tong et $\mathrm{al}^{31,37}$ and Babikian et $\mathrm{al}^{38}$ have both shown that SWI has 3-6 times the sensitivity of conventional T $2^{\star} \mathrm{GE}$ sequences for detecting the size, number, volume, and distribution of hemorrhagic lesions in diffuse axonal injuries.

In our study, we detected the hemorrhagic component with SWI in 42 of a total of 53 lesions. Despite the SWI data, $\mathrm{T} 2{ }^{\star} \mathrm{GE}$ and T2 FSE could only detect 3 and 2 hemorrhagic lesions, respectively. In addition to hemorrhagic lesions in SWI, 6 lesions exhibited prominent venous structures, 2 displayed occlusion of thalamostriate veins, and 1 revealed a collateral venous structure. Eight lesions were shown with SWI, but these lesions were not detected with $\mathrm{T} 2{ }^{\star} \mathrm{GE}$ or T2 FSE. Nine lesions that were detected with SWI could not be observed with T2 FSE, and 14 lesions that were detected with SWI could not be detected with $\mathrm{T} 2{ }^{\star} \mathrm{GE}$. However, 2 lesions were not detected with SWI, but they were observed to be hyperintense with $\mathrm{T} 2{ }^{\star} \mathrm{GE}$ and T2 FSE. In this condition, despite hemorrhagic lesions that accompanied other venous pathologies shown sensitively by SWI, some of the nonhemorrhagic lesions could not be determined, probably because of low anatomic resolution or because of nonhemorrhagic gliosis in the chronic period. Thus, although SWI shows almost all of the hemorrhagic lesions, it is insensitive to some of the nonhemorrhagic lesions. Therefore, T2 FSE and $2^{*} \mathrm{GE}$ examinations should be used together with SWI to establish both hemorrhagic and nonhemorrhagic Behçet lesions. No remnant of hemorrhage was found in $2 \mathrm{NBD}$ cases with advanced brain atrophy and extensive infiltration. This outcome may suggest that previous remnants of hemorrhage may be resorbed subsequently in chronic BD or that there is possibly a different nonhemorrhagic pathophysiologic mechanism. Calcification cannot be definitively identified by MR imaging because its signals are variable on conventional spin-echo T1- or T2weighted images and cannot be differentiated from hemorrhage by gradient-echo images because both will cause local magnetic field changes and appear as hypointensities. However, phase images on SWI can help differentiate calcification from hemorrhage because calcification is diamagnetic, whereas hemorrhage is paramagnetic, resulting in opposite signal intensities. ${ }^{13,28}$

Some studies have suggested that venous involvement may be the primary cause of parenchymal injury. However, arterial involvement was suggested by Hirohata. ${ }^{23}$ We consider all neuropathologic studies because both arterial and venous perivascular infiltration constitute NBD involvement. Indeed, arterial ischemia may cause white infarcts without hemorrhaging. In contrast, obvious venous ischemia is generally hemorrhagic in pathology. Cerebral venous ischemia leads to parenchymal injury because of locally increased venous pres- 


\begin{tabular}{|c|c|c|c|c|c|c|c|c|c|}
\hline \multirow[b]{2}{*}{$\begin{array}{l}\text { Case } \\
\text { No. }\end{array}$} & \multirow[b]{2}{*}{ Age } & \multirow[b]{2}{*}{ Sex } & \multirow[b]{2}{*}{$\begin{array}{l}\text { Lesion } \\
\text { No. }\end{array}$} & \multirow[b]{2}{*}{$\begin{array}{l}\text { Locations of } \\
\text { Lesions }\end{array}$} & \multicolumn{4}{|c|}{ Signal Intensity in Lesions } & \multirow[b]{2}{*}{ Other Findings } \\
\hline & & & & & T2 FSE & $\mathrm{T} 2 * \mathrm{GE}$ & $\begin{array}{c}\text { SWI } \\
\text { Magnitude }\end{array}$ & $\begin{array}{l}\text { SWI } \\
\mathrm{mIP}\end{array}$ & \\
\hline \multirow[t]{2}{*}{1} & 44 & $\mathrm{~F}$ & 1 & Putamen & Hyper & Hyper & Hyper & Hyper & \\
\hline & & & 2 & Mesencephalon & & Нуро & Нуро & Нуро & \\
\hline \multirow[t]{2}{*}{2} & 39 & $\mathrm{~F}$ & $3,4,5$ & Pons & Hyper & Hyper & Нуро & Нуро & \\
\hline & & & 6 & Medulla oblongata & Hyper & Hyper & & & \\
\hline \multirow[t]{2}{*}{3} & 31 & M & 7 & Pons & & & Нуро & Нуро & \\
\hline & & & 8 & Pons & Hyper & Hyper & Нуро & Нуро & \\
\hline 4 & 40 & M & 9 & Putamen & Нуро & Нуро & Нyро & Нуро & \\
\hline 5 & 31 & M & 10 & Pons & Hyper & Hyper & Нyро & Нyро & \\
\hline \multirow[t]{2}{*}{6} & 44 & $\mathrm{~F}$ & 11 & Thalamus & & & Нyро & Нуро & \\
\hline & & & 12 & Thalamus & & & Нyро & Нyро & PVS \\
\hline 7 & 36 & M & & & & & & & BSA \\
\hline \multirow[t]{2}{*}{8} & 52 & $\mathrm{~F}$ & 13,14 & Putamen & Hyper & & Нуро & Нуро & \\
\hline & & & 15 & Putamen & Hyper & Hyper & Hyper & Hyper & \\
\hline \multirow[t]{2}{*}{9} & 41 & M & 16 & Pons & & & Нуро & Нуро & BSA \\
\hline & & & 17,18 & Medulla oblongata & Hyper & Hyper & Hyper & Hyper & BSA \\
\hline 10 & 46 & $F$ & & & & & & & BSA \\
\hline \multirow[t]{4}{*}{11} & 38 & M & 19 & Thalamus & Hyper & Hyper & Нуро & Нуро & BSA \\
\hline & & & 20,21 & Pons & Hyper & & Нуро & Нуро & BSA \\
\hline & & & 22 & Medulla oblongata & Hyper & Hyper & & & BSA \\
\hline & & & 23 & Pons & Hyper & Hyper & Нуро & Нуро & BSA \\
\hline \multirow[t]{2}{*}{12} & 30 & M & 24 & Thalamus & & & Нуро & Нуро & \\
\hline & & & 25,26 & Pons & Hyper & & Нуро & Нуро & \\
\hline \multirow[t]{2}{*}{13} & 37 & $\mathrm{~F}$ & 27 & Pons & Hyper & Hyper & Нуро & Нyро & BSA \\
\hline & & & 28 & Medulla oblongata & & & Нуро & Нуро & BSA \\
\hline 14 & 45 & M & 29 & Thalamus & Hyper & Hyper & Нуро & Нуро & PVS \\
\hline \multirow[t]{2}{*}{15} & 27 & $\mathrm{~F}$ & 30 & Thalamus & & & Нуро & Нуро & PVS \\
\hline & & & 31 & Mesencephalon & Нуро & Нуро & Нyро & Нуро & \\
\hline \multirow[t]{2}{*}{16} & 44 & M & 32 & Corona radiata & Hyper & Hyper & Нуро & Нуро & PVS \\
\hline & & & 33 & Capsula interna & Hyper & Hyper & Нуро & Нуро & \\
\hline 17 & 20 & $\mathrm{~F}$ & 34 & Splenium of CC & & & Нуро & Нуро & \\
\hline \multirow[t]{2}{*}{18} & 36 & $\mathrm{~F}$ & 35 & Caudate nucleus & Hyper & Hyper & Нyро & Нyро & PVS \\
\hline & & & 36 & Pons & Hyper & Hyper & Нуро & Нуро & \\
\hline \multirow[t]{4}{*}{19} & 34 & $\mathrm{~F}$ & 37 & Corona radiata & Hyper & Hyper & Hyper & Hyper & \\
\hline & & & 38 & Thalamus & Hyper & Hyper & Hypo & Нyро & \\
\hline & & & 39,40 & Pons & Hyper & Hyper & Hyper & Hyper & \\
\hline & & & 41 & Medulla oblongata & Hyper & Hyper & Hyper & Hyper & \\
\hline 20 & 41 & M & 42 & Caudate nucleus & Hyper & Hyper & Нуро & Нyро & Occlusion of TSV and CV \\
\hline & & & 43 & Putamen & Hyper & Hyper & Нуро & Нуро & \\
\hline & & & 44 & Mesencephalon & Hyper & Hyper & Нyро & Нуро & \\
\hline & & & 45 & Pons & Hyper & Hyper & Нуро & Нуро & \\
\hline 21 & 40 & $\mathrm{~F}$ & 46 & Caudate nucleus & Hyper & Hyper & Нуро & Нуро & Occlusion of TSV \\
\hline & & & 47,48 & Mesencephalon & Hyper & Hyper & Нуро & Нуро & \\
\hline & & & 49,50 & Pons & Hyper & Hyper & Нуро & Нуро & \\
\hline 22 & 39 & $\mathrm{~F}$ & 51 & Pons & Hyper & Hyper & Нуро & Нуро & PVS, BSA \\
\hline & & & 52 & Medulla oblongata & Hyper & Hyper & Нyро & Нуро & BSA \\
\hline 23 & 35 & M & 53 & Temporal lobe & & & & & Arterial ischemia \\
\hline
\end{tabular}

sure, which exceeds the pressure generated by the arteries. Because of leaking of blood into the damaged area, infarcts are more likely to encounter hemorrhagic transformation than arterial types of ischemic stroke. ${ }^{39}$ Previous neuropathologic studies generally did not examine lesions for iron accumulation, hemorrhage, or remnants of hemorrhage. Landeyro et $\mathrm{al}^{40}$ presented a case of an autopsy of an NBD patient in whom multiple hemorrhagic infarctions were found in the brain stem. Microscopic examination revealed generalized perivascular lymphocytic and neutrophilic inflammation in small and medium vessels with intense diapedesis bleeding. This phenomenon was predominant in the brain stem. Similarly, for this case, parenchymal NBD lesions with SWI were found to be hemorrhagic. Thus, parenchymal lesions in NBD are probably associated with venous structures. In our study, almost all hemorrhagic findings resulted from venous lesions, though in pathologic studies, both arterial and venous vascular structures generally are infiltrated, which requires clarification. Because the arterial wall is thicker and more elastic than the venous wall and the luminal pressure is higher in arteries, we believe that veins are more frequently affected, because of the external mechanical effects and inflammatory chemical substances, which have a higher potential impact on the thinner venous wall and lower venous luminal pressure. ${ }^{41}$ In our study, 1 of 23 patients demonstrated arterial infiltration, whereas we believe that the others probably showed venous infiltration. Importantly, in our study, because our approach is supported, 42 of 52 lesions were hemorrhagic, 
venous occlusions were shown in deep venous structures in some cases, irregularities of venous contours were observed, and venous collateral structures were revealed.

In patients with prior large cerebral hemorrhage or chronic hypertension, the prevalence of microhemorrhages were reported to be between $57 \%$ and $78 \% .{ }^{42}$ Similarly, in patients with traumatic brain injury, it is known that microhemorrhages may occur. ${ }^{28}$ Therefore, patients with neurologic or other diseases involving the central nervous system, traumatic brain injury, and hypertension were excluded from this study.

An important limitation of our study is the lack of sufficient cases, which prevented the classification of acute, subacute, and chronic lesions into separate groups. The interpretation of acute, subacute, and chronic lesions could be beneficial for understanding pathogenesis and the prognostic process. The present study was performed by using a $1.5 \mathrm{~T} \mathrm{MR}$ device. Comparing 1.5T with $3 \mathrm{~T}$ and $7 \mathrm{~T}$ high-field devices, the high-field SWI technique may provide a more detailed description about venous structures. Thus, using high Tesla devices could be advantageous for revealing venous pathologies in future studies. In the present study, the data were collected prospectively from patients who visited our tertiary outpatient clinics for a relatively short time, and further examinations were not performed. Future studies by using SWI in a larger number of NBD cases and for longer times such as 5 or 10 years may provide further information about the generation and evolution of the lesions.

\section{Conclusions}

SWI is a new imaging method for the detection of lesion characteristics in parenchymal NBD. Compared with both T2 FSE and $\mathrm{T} 2{ }^{*} \mathrm{GE}$ sequences, SWI demonstrated hemorrhagic foci in many more lesions; this superiority was statistically significant. In addition, in the lesion vicinity, prominent venous structures, as well as the occlusion of venous and collateral venous structures, were revealed with SWI. Venous effects and venous theory in parenchymal NBD are supported by the existence of hemorrhagic foci and accompanied venous pathology in most of the lesions detected by SWI.

\section{References}

1. Behçet $H$. Über residivierende, aphtöse durch ein Virus verursachtes Geschwüre am Mund, am Auge und an der Genitalien. Derm Wschr 1937;105: 1152-57

2. Borhani Haghighi A, Pourmand R, Nikseresht AR. Neuro-Behçet disease. A review. Neurologist 2005;11:80-89

3. Al-Araji A, Kidd DP. Neuro-Behçet's disease: epidemiology, clinical characteristics, and management. Lancet Neurol 2009;8:192-204

4. Siva A, Altintas A, Saip S. Behçet's syndrome and the nervous system. Curr Opin Neurol 2004;17:347-57

5. Akman-Demir G, Serdaroglu P, Tasçi B. Clinical patterns of neurological involvement in Behçet's disease: evaluation of 200 patients. The Neuro-Behçet Study Group. Brain 1999;122:2171-82

6. Siva A, Saip S. The spectrum of nervous system involvement in Behçet's syndrome and its differential diagnosis. J Neurol 2009;256:513-29

7. Kocer N, Islak C, Siva A, et al. CNS involvement in neuro-Behcet syndrome: an MR study. AJNR Am J Neuroradiol 1999;20:1015-24

8. Kidd D, Steuer A, Denman A M, et al. Neurological complications in Behcet's syndrome. Brain 1999;122:2183-94

9. Akman-Demir G, Bahar S, Coban O, et al. Cranial MRI in Behcet's disease: 134 examinations of 98 patients. Neuroradiology 2003;45:851-59

10. Hadfield MG, Aydin F, Lippman HR, et al. Neuro-Behcet's disease. Clin Neuropathol 1997;16:55-60
11. Mirsattari S, McGinn, G, Halliday WC. Neuro-Behcet disease with predominant involvement of the brainstem. Neurology 2004;63:382-84

12. Siva A, Kantarci OH, Saip S, et al. Behçet's disease: diagnostic and prognostic aspects of neurological involvement. J Neurol 2001;248:95-103

13. Haacke EM, Mittal S, Wu Z, et al. Susceptibility-weighted imaging: technical aspects and clinical applications, part I. AJNR Am J Neuroradiol 2009;30:19-30

14. The International Study Group for Behçet's Disease. Evaluation of diagnostic ("classification") criteria in Behçet's disease: towards internationally agreed criteria. Br J Rheumatol 1992;31:299-308

15. Silfverskiold BP. Recurrent Uveitis (Behçet's syndrome) and encephalomyelomeningitis. Acta Psychiatr Neurol Scand 1951;26:443-53

16. McMenemey WH, Lawrence BJ. Encephalomyelopathy in Behçet's disease: report of necropsy findings in two cases. Lancet 1957;2:353-58

17. Rubinstein LJ, Ulrich H. Meningo-encephalitis of Behçet's disease: case report with pathological findings. Brain 1963;86:151-60

18. Kawakita H, Nishimura M, Satoh Y, et al. Neurological aspects of Behçet's disease. A case report and clinico-pathological review of the literature in Japan. J Neurol Sci 1967;5:417-39

19. Totsuka S, Hattori T, Yazaki M, et al. Clinicopathologic studies on neuroBehçet's disease. Folia Psychiatr Neurol Jpn 1985;39:155-66

20. Geny C, Cesaro P, Heran F, et al. Pseudutumoral neuro-Behçet disease. Surg Neurol 1993;39:374-76

21. Arai T, Mizukami K, Sasaki M, et al. Clinicopathological study on a case of neuro-Behçet disease: in special reference to MRI, SPECT and neuropathological findings. Jpn J Psychiatry Neurol 1994;48:77-84

22. Hadfield MG, Aydin F, Lippman HR, et al. Neuro-Behçet's disease. Clin Neuropathol 1996;15:249-55

23. Hirohata S. Histopathology of central nervous system lesions in Behçet's disease. J Neurol Sci 2008;267:41-47

24. Scardamaglia L, Desmond PM, Gonzales MF, et al. Behçet's disease with cerebral vasculitis. Int Med J 2001;31:560-61

25. Reichenbach JR, Venkatesan R, Schillinger DJ, et al. Small vessels in the human brain: MR venography with deoxyhemoglobin as an intrinsic contrast agent. Radiology 1997;204:272-77

26. Haacke EM, Xu Y, Cheng YC, et al. Susceptibility weighted imaging (SWI). Magn Reson Med 2004;52:612-18

27. Sehgal V, Delproposto Z, Haacke EM, et al. Clinical applications of neuroimaging with susceptibility-weighted imaging. J Magn Reson Imaging 2005;22: 439-50

28. Mittal S, Wu Z, Neelavalli J, et al. Susceptibility-weighted imaging: technical aspects and clinical applications, part 2. AJNR Am J Neuroradiol 2009;30: 232-52

29. Reichenbach JR, Haacke EM. High-resolution BOLD venographic imaging: a window into brain function. NMR Biomed 2001;14:453-67

30. Wycliffe ND, Choe J, Holshouser B, et al. Reliability in detection of hemorrhage in acute stroke by a new three-dimensional gradient recalled echo susceptibility-weighted imaging technique compared to computed tomography: a retrospective study. J Magn Reson Imaging 2004;20:372-77

31. Tong KA, Ashwal S, Holshouser BA, et al. Hemorrhagic shearing lesions in children and adolescents with posttraumatic diffuse axonal injury: improved detection and initial results. Radiology 2003;227:332-39

32. Pinker K, Stavrou I, Szomolanyi P, et al. Improved preoperative evaluation of cerebral cavernomas by high-field, high-resolution susceptibility-weighted magnetic resonance imaging at 3 Tesla: comparison with standard $(1.5 \mathrm{~T})$ magnetic resonance imaging and correlation with histopathological findings—-preliminary results. Invest Radiol 2007;42:346-51

33. Essig M, Reichenbach JR, Schad LR, et al. High-resolution MR venography of cerebral arteriovenous malformations. Magn Reson Imaging 1999;17:1417-25

34. Haacke EM, Cheng NY, House MJ, et al. Imaging iron stores in the brain using magnetic resonance imaging. Magn Reson Imaging 2005;23:1-25

35. Sehgal V, Delproposto Z, Haddar D, et al. Susceptibility-weighted imaging to visualize blood products and improve tumor contrast in the study of brain masses. J Magn Reson Imaging 2006;24:41-51

36. Haacke EM, DelProposto ZS, Chaturvedi S, et al. Imaging cerebral amyloid angiopathy with susceptibility-weighted imaging. AJNR Am J Neuroradiol 2007;28:316-17

37. Tong KA, Ashwal S, Holshouser BA, et al. Diffuse axonal injury in children: clinical correlation with hemorrhagic lesions. Ann Neurol 2004;56:36-50

38. Babikian T, Freier MC, Tong KA, et al. Susceptibility weighted imaging: neuropsychologic outcome and pediatric head injury. Pediatr Neurol 2005;33: 184-94

39. Stam J. Thrombosis of the cerebral veins and sinuses. $N$ Engl J Med 2005;28:1791-98

40. Landeyro J, Vidaur-Tello L, García-Fontgivell JF, et al. Neuro-Behcet clinicopathological findings in an autopsy case. Rev Neurol 2008;47:575-78

41. Junqueira LC, Carneiro J. Basic Histology: Text \& Atlas, 11th ed. New York: McGraw Hill; 2005:205-17

42. Jeong JH, Yoon SJ, Kang SJ, et al. Hypertensive pontine microhemorrhage. Stroke 2002;33:925-29 